\title{
Inscribing History, (Over)Writing Politics: Word and Image in the Chapel of Sant'Isidoro at San Marco, Venice
}

Debates about the material, visual and perceptual aspects of inscriptions, and concerning interactions between verbal and pictorial modes of representation have been particularly vibrant in recent years. ${ }^{1}$ This essay contributes to such discussions by exploring how the epigraphic apparatus of the chapel of Sant'Isidoro in San Marco, Venice, functioned as a source of historical verification and of religious and political validation. The chapel is a small, one-bay rectangular room located in the north transept of the basilica, decorated with a lavish cycle of mosaics that were begun during the dogate of Andrea Dandolo (r.1343-54) and completed in 1355, shortly after his death (Fig. 1). ${ }^{2}$ The body of the eponymous saint rests inside an elaborately sculpted shrine placed at the east end of the chapel, in a raised position behind the altar (Fig.2). Above it, the vault mosaics retell the most significant episodes of the life and martyrdom of St Isidore through vividly coloured images and lengthy textual captions, and celebrate his translation from Chios to Venice in the twelfth century (Fig. 3-4). The figurative programme also comprises a commanding image of Christ, enthroned between St Mark and St Isidore on the east wall (Fig. 5); and a representation of the Virgin between St John the Baptist and St Nicholas in the lunette of the west wall (Fig.6). Upon entering the room, the viewer's gaze is captured by a multi-line mosaic inscription that occupies the middle register of the east wall (Fig. 2 and 5). The inscription, whose length, density and visual pre-eminence have few parallels in the basilica, reads:

+CORP[US] B[EA]TI YSIDORI, P[RAESE]NTI AR[C]HA CLAUDIT[UR], VENEC[IAS] DELAT[UM] A CHIO P[ER] D[OMI]NU[M] D[OMI]NICU[M] MICHAEL, IN/CLITU[M] VENEC[IARUM] DUCE[M], I[N] MCXXV Q[UO]D OCULTE I[N] ECC[LESIA] S[ANCTI] MARCI P[ER]MA[N]SIT USQ[UE] AD I[N]CEPCIO/NEM EDIFICACIO[N]IS HUI[US] CAPELE SUO NO[M]I[N]E EDHIFICAT[E] I[N]CEPT[E] DUCA[N]TE D[OMI]NO A[N]DREA DA[N]DU/LO, I[N]CLITO VENEC[IARUM] DUCE [ET] T[EM]P[O]R[E] NOBILIU[M] VIRO[RUM]

\footnotetext{
1 In addition to the volumes in the present series, Lieb, Ludger (ed.), 2014ff., available online, in open access: https://www.degruyter.com/view/serial/428997, see at least Mostert/Adamska (eds.) 2014a; Mostert/Adamska (eds.) 2014b; Eastmond (ed.) 2015; Bedos-Rezak/Hamburger (eds.) 2016.

2 The most comprehensive overview of the chapel is La Cappella Di Sant'Isidoro 2008. In addition, see De Franceschi 2003, De Franceschi 2008 and Klein 2010.
}

I would like to thank the editors of this volume, Wilfried E. Keil and Kristina Krüger, for their valuable comments and support. I am also grateful to Tom Nickson for his attentive reading and precious insights. Research on this article has benefited from the support of ASK Research Center. 
D[OMI]NOR[UM] MARCI LAUREDANO [ET] IOH[ANNIS] DELPHI/N[O], P[RO]CUR[ATORUM] ECC[LESIE] S[ANCTI] MARCI [ET] [COM]PLECTE DUCA[N]T[E] D[OMI]NO IOHA[NN]E G[RA]DO[N]ICHO I[N]CLIT[O] VENEC[IARUM] DUCE [ET] T[EM]P[O]R[E] / NOBILIU[M] VIRO[RUM] D[OM]INOR[UM] MARCI LAUREDANO [ET] NICOLAI LIO[N] ET IOH[ANN]I[S] DELPHIN[O] P[RO]CUR[ATORUM] ECC[LESIE] S[ANCTI] MARCI I[N] $\mathrm{M} / \mathrm{CCCLV}, \mathrm{ME}[\mathrm{N}] \mathrm{SE}$ JULII, DIE $\mathrm{x}$.

In this sepulchre lies the body of St Isidore, which was brought from Chios to Venice by Domenico Michiel, the noble doge of the Venetians, in 1125. The body remained hidden in the church of San Marco until the construction of this chapel, which was dedicated to his name, was begun. This occurred during the rule of Andrea Dandolo, the illustrious doge of the Venetians, at the time when the noble gentlemen Marco Loredan and Giovanni Dolfin were the procurators of the church of San Marco. [The chapel] was completed under the rule of Giovanni Gradenigo, the illustrious doge of the Venetians, and in the time of the noble lords Marco Loredan, Nicolo Lion, and Giovanni Dolfin, procurators of the church of San Marco, on 10 July $1355 .^{3}$

At a first level, this inscription fulfils a straightforward declarative and celebratory purpose. It clarifies the function of the chapel, delivering information about the place of origin of the holy body that it preserves, and about the date of Isidore's translation to Venice. In addition, it provides the names of the public officers who oversaw the construction and decoration of the shrine, and states the date of its completion. However-as Robert Favreau reminds us-commemorative inscriptions have more agency than this. ${ }^{4}$ Publicly and durably recording specific names, dates, and events, dedicatory inscriptions are also historical objects. As such, they result from a process of factual selection, inclusion and exclusion that embeds, reflects and produces specific cultural and ideological regimes. Any commemorative inscription therefore represents an expression of authority: firstly, the authority of those individuals or groups whose names and voices it commits to posterity; secondly, the power of those who elect and control the public display of texts, and, by extension, the codification of public memory, into a durable form..$^{5}$ This essay advances two chief arguments. First, that the textual programme of the chapel of Sant'Isidoro dramatized the complex interactions between public writing, historical construction, and enunciations of political and religious power. Second, that it did so at a highly critical juncture, when the legitimacy and stability of Venice's rule were being tested, and as the mechanics of juridical and historical validation became increasingly intertwined with documentary and archival practices. Throughout this chapter, the inscriptions in the chapel of Sant'Isidoro will be discussed as 'public' texts. At one level, this term is simply used to indicate that the epigraphs were set up in the expectation of a collective readership. As was often the case with the more sacred areas of medieval churches, entry to the

3 Transcribed and translated into Italian in Andaloro/Demus (eds.) 1990, vol. 2, 196. English version is by the present author.

4 Favreau 1989, 214.

5 For a succinct discussion of the correlations between public writing and power structures, see Petrucci 2002, 18. 


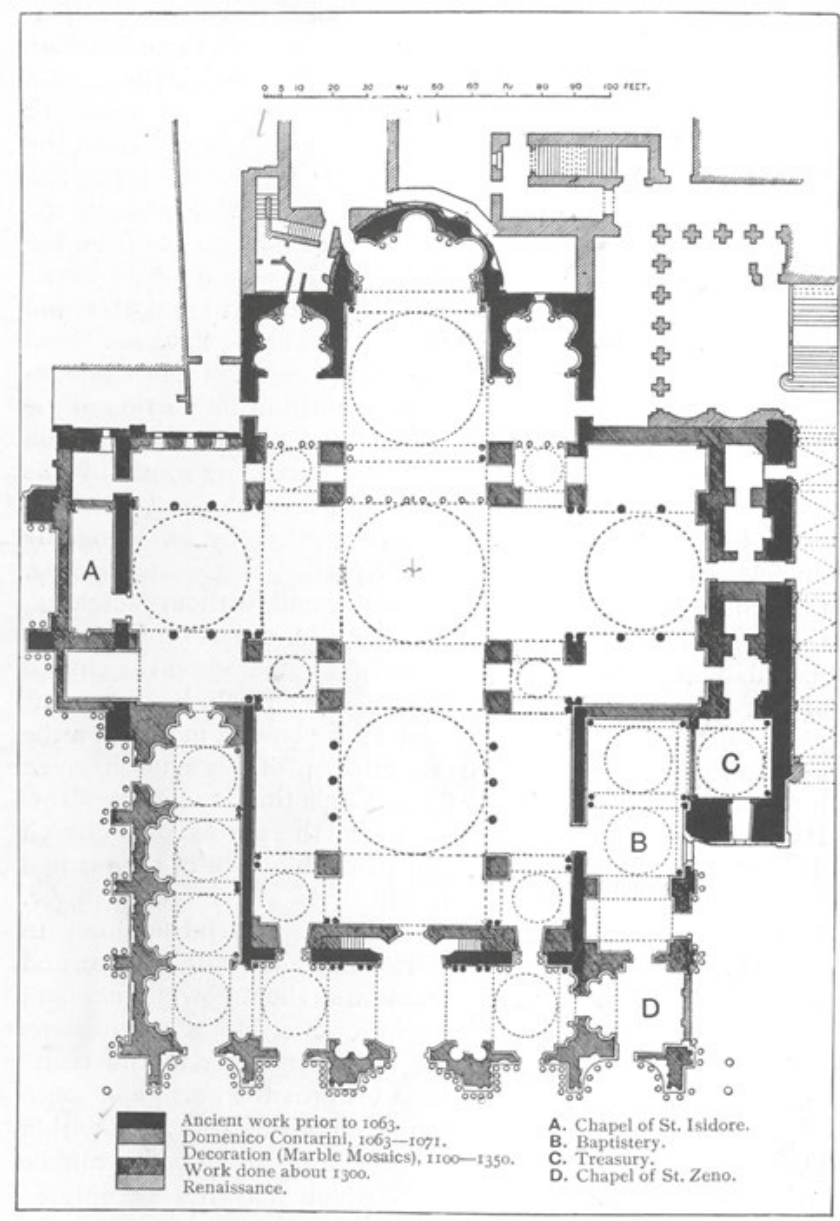

Fig. 1: Venice, San Marco, Ground plan.

chapel of Sant'Isidoro, which preserved the body of a saint, was probably restricted. Nevertheless, the chapel would have been accessible to a range of viewers, including-at the very least-the clergy of San Marco, the procurators of the basilica, and the doge. ${ }^{6}$ At a second level, the term 'public' will be employed to express the imbrications between the textual and visual programmes of the chapel of Sant'Isidoro and the Venetian 'res publica'. San Marco was the state church of Venice, and St Isidore's

6 As will be discussed below, starting from 1356 a public procession was held yearly on the Piazza San Marco and inside the basilica on 16 April, feast-day of the translation of St Isidore to Venice. The procession involved a broad spectrum of the Venetian civic community: the doge, members of the higher organs of the Venetian government, the clergy of the basilica and all major Venetian confraternities. While we know that the doge and his retinue did attend mass in the chapel on this occasion, further research into Venice's liturgical tradition, which is largely unpublished, may elucidate how accessible the shrine was to other participants in the procession, and to the wider congregation. 
shrine was a public artistic commission, its creation directly instigated by the government. In addition, its inscriptions explicitly referenced the highest magistracies of the Venetian state-making these epigraphs important witnesses to Venice's late medieval esprits d'État. ${ }^{7}$

The central decades of the fourteenth century were a particularly troubled phase of Venetian history. ${ }^{8}$ Venice was gripped by plague in 1348 , and an earthquake hit the city that same year. ${ }^{9}$ On the international stage, Venice's commercial hegemony was threatened by the ever more aggressive claims of its chief competitor, Genoa, leading the two cities to fight an uncompromising war between $1350-55 .{ }^{10}$ Finally, Venetian internal politics was also fraught with tensions. In 1297, the constitutional act known as the Serrata del Maggior Consiglio had restricted eligibility for the Venetian Great Council to old aristocratic families, inaugurating a long period of intense strife. In the decades that followed, the foundations and structures of the Venetian government, and the specific functions of the doge, underwent a comprehensive revision. ${ }^{11}$ In his attempts to steer the government through these critical challenges, Andrea Dandolo demonstrated acute awareness of the power of images and of the written word as agents of legal and political certification and stabilization. He initiated an ambitious artistic campaign in San Marco, which comprised the building and decoration of the chapel of Sant'Isidoro and of the baptistery of the basilica; the makeover of the Byzantine Pala d'Oro, which had been in place at the high altar of San Marco since the twelfth century; the commissioning of Paolo Veneziano's pala feriale; and the making of three lavish liturgical manuscripts for use in the basilica. ${ }^{12}$ In addition to supervising these projects, Dandolo also championed a comprehensive systematization of

7 I borrowed the term esprits d'État from Bourdieu 1993, a powerful and provocative meditation on the interrelations between state, public institutions and symbolic productions.

8 A brief but effective introduction to the challenges of Andrea Dandolo's dogate described in the following paragraph is found in the introduction to Dandolo 1942, VIII.

9 Brunetti 1909; and Venezia E La Peste, 1348-1797 1980². Both the plague and the earthquake of 1348 are commemorated in a coeval vernacular inscription, located in the tympanum above a (walled-in) portal in the courtyard of the Scuola di Santa Maria della Carità in Venice (the Accademia). The inscription is published in Stussi 1997, 166-168, and fig. 47.

10 Balard 1997 provides an excellent introduction to the conflict.

11 Literature on this topic is vast. See at least Cracco 1967, 211-350; Lane 1971; and Chojnacki 1997.

12 On the baptistery, see Pincus 1990; Horn 1991; Pincus 1996a; Pincus 1996b; Pincus 2000; Pincus 2010; De Franceschi 2013. The standard reference on the pala d'oro and pala feriale is Hahnloser and Polacco 1994. On the liturgical manuscripts commissioned by Dandolo, see Katzenstein 1987. For a general discussion of Dandolo's projects, see also Klein 2010. Most recently, see Marangon 2016, which explores the influence of Greek epigraphy on the style of the inscriptions included in Dandolo's artistic commissions at San Marco, particularly the pala feriale and the baptistery. It interprets them in connection with Venice's proto-humanism, and with its enduring attraction towards Byzantine and ancient Greek culture. 


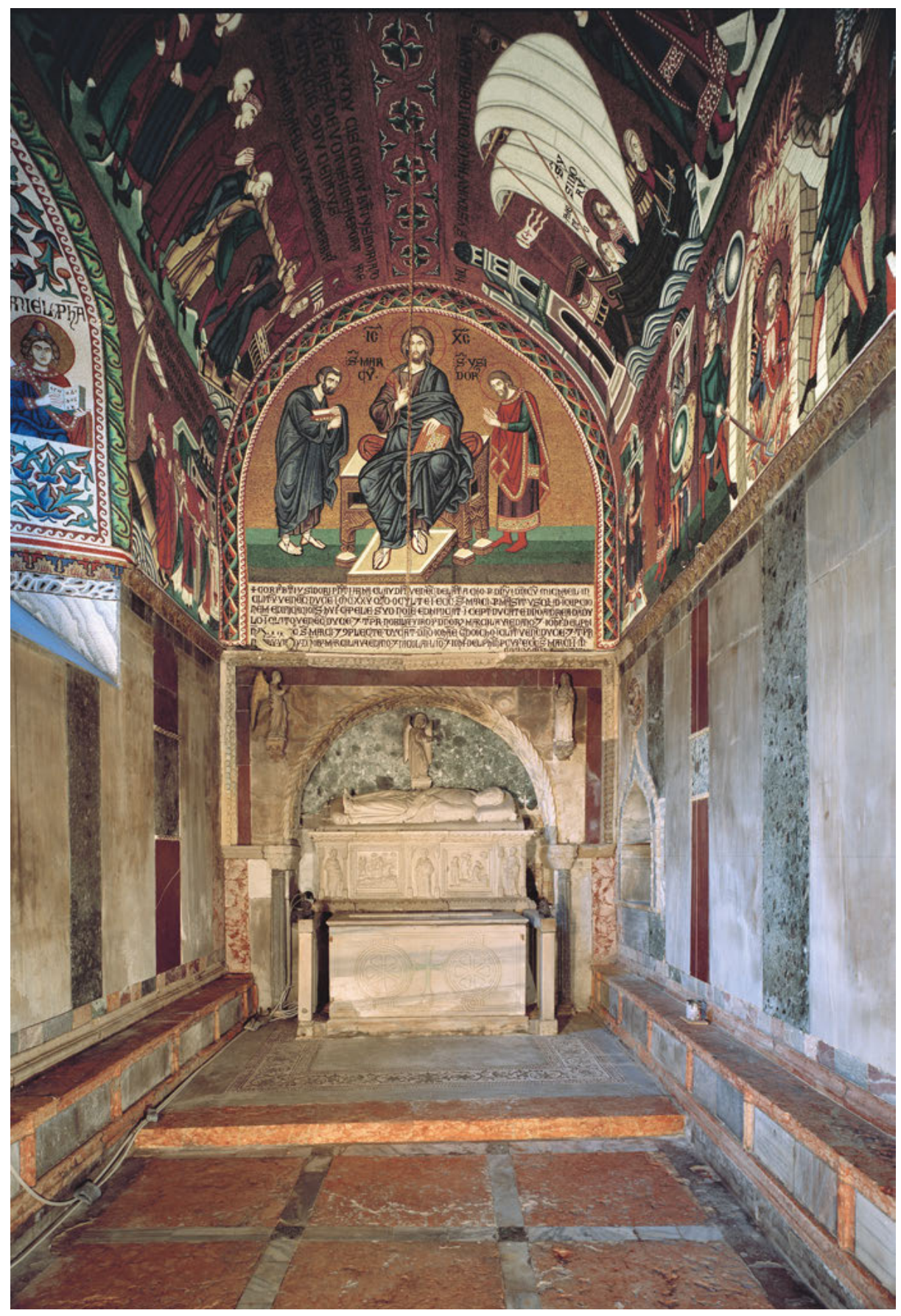

Fig. 2: Venice, San Marco, Chapel of Sant'Isidoro, interior looking east, completed 1355. 
Fig. 3: Venice, San Marco, Chapel of Sant'Isidoro, vault, north side.

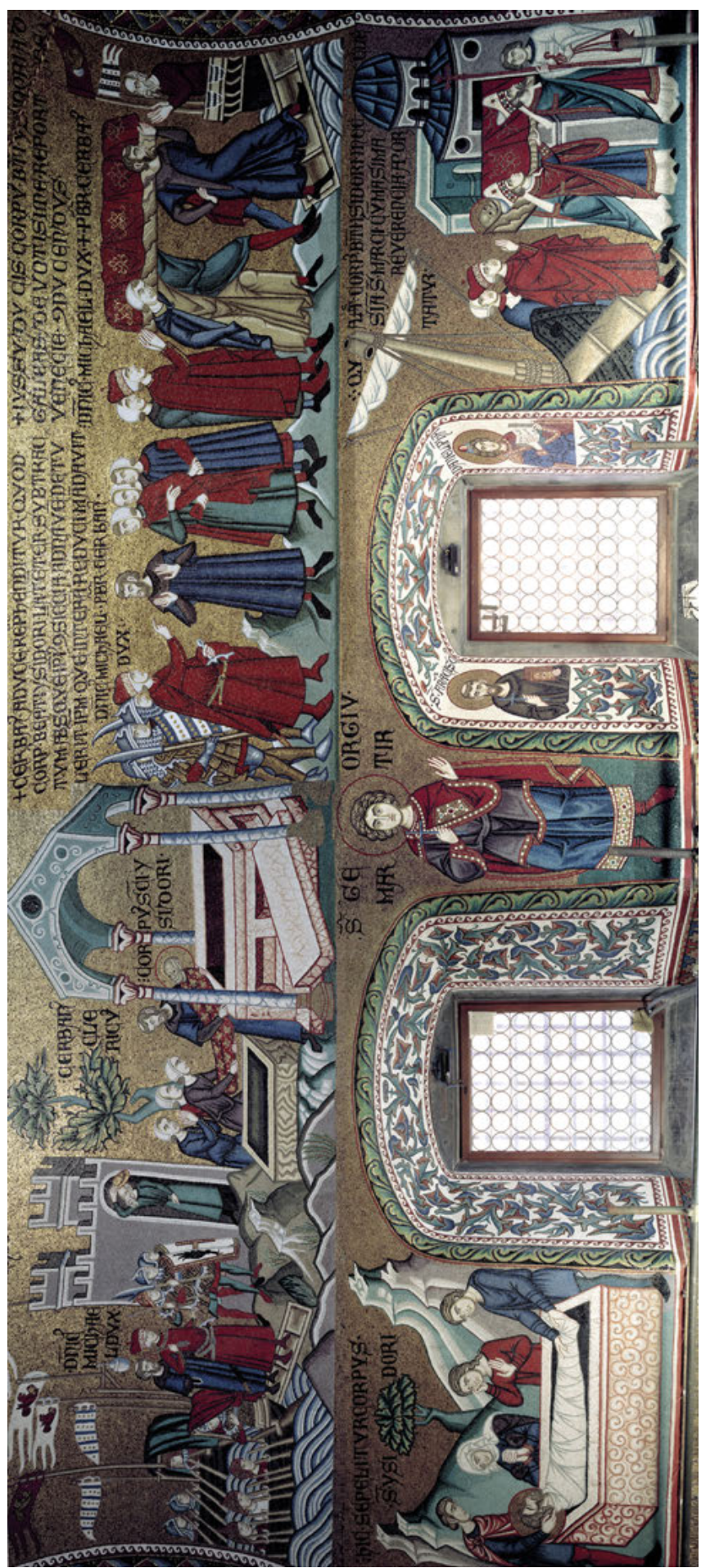




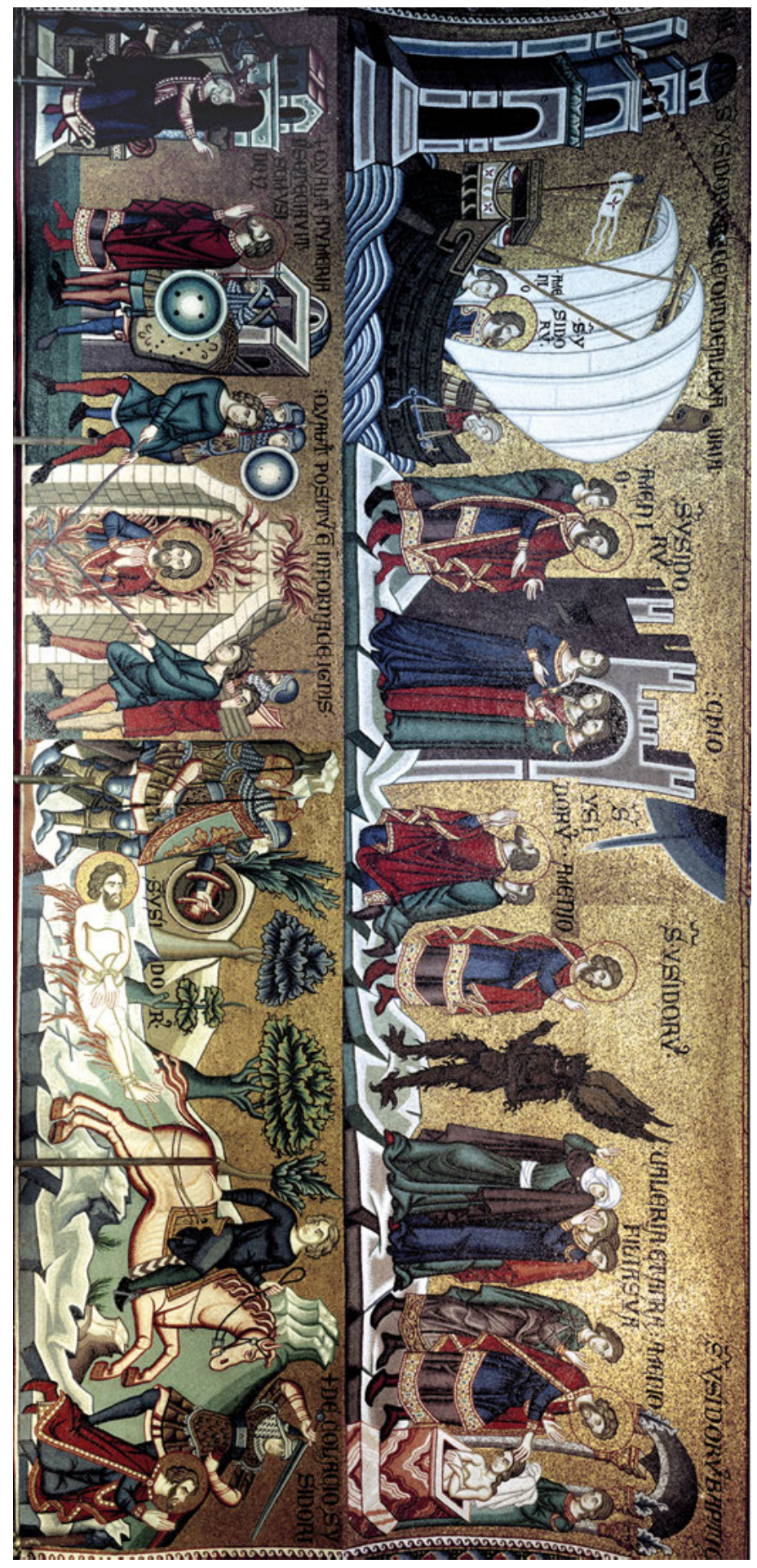

Fig. 4: Venice, San Marco, Chapel of Sant'Isidoro, vault, south side. 
Venetian written laws, and-the first doge to have ever attempted this-he authored a written history of Venice. ${ }^{13}$

The inscriptions in the chapel of Sant'Isidoro should be examined in relation to this complex artistic, legal, and historical palimpsest. Deftly joining sacred events with the political history of the city, and inscribing them permanently on the walls of San Marco, the inscriptions renewed a consolidated Venetian tradition of historical and visual memorialization that cast the city as divinely favoured against current political and military uncertainties. Also, by publicly recording-for the first time in the basilica-lists of names of individual doges and procurators, and celebrating their joint efforts to honour the body of St Isidore, the inscriptions promoted a highly specific political vision that emphasised collective action and institutional stability and continuity. But how did the inscriptions in the chapel of Sant'Isidoro convey such complex meanings-both textually and visually? In what ways did they interact with the figurative mosaics around them? Who would actually see the inscriptions, and in what contexts? To what extent did individual inscriptions gesture to each other, working as a textual and spatial ensemble? Finally, what other documentary, discursive or performative frameworks did they engage with? A valuable point of departure for addressing these questions is offered by two notorious passages from Martino Da Canale's Histories of Venice.

\section{Word as Image, Image as Word: Martino da Canale's Histories of Venice and Late Medieval Venetian Attitudes Towards Public Writing and Imaging}

The Histories of Venice, written in the third quarter of the thirteenth century, are punctuated with references to the relative significance of words and images in processes of historical verification, and with comments about the political import of historical writing. In the prologue to the second part of his chronicle, which explains why he set out to write a history of Venice, Canale wrote:

We see writing and painting with our eyes, so that when one sees a story painted or hears a naval or land battle recounted or reads about the deeds of his ancestors in a book, he seems to be present at the scene of the battle. And since events live thanks to paintings and oral accounts

13 Detailed (and often divergent) discussions of Andrea Dandolo's dogate and of his historical and legal undertakings can be found in Simonsfeld 1877; Cracco 1967; Cracco 1976; Ravegnani 1986; and Arnaldi 1970. 
and writing, I have undertaken to occupy myself with the deeds that the Venetians have accomplished in the service of the holy church and in honour of their noble city. ${ }^{14}$

In an earlier passage, and following a well-established tradition of Venetian civic religion, Canale had singled out the basilica of San Marco, the chief religious building of medieval Venice and a primary locus where the city's social and political identity was defined, in order to elucidate the function of images as tokens of historical certification. Concluding his account of the myth of foundation of the city of Venice-the translation of the body of St Mark from Alexandria in the ninth century-the thirteenth-century historian remarked:

If you wish to verify that those things happened just as I told you, come to see the beautiful church of San Marco in Venice, and look at it right in front, because this story is written there just as I have told it to you. ${ }^{15}$

Canale's texts provide precious insights into how written words and images were viewed and understood by medieval Venetian viewers, thus offering clues about the interactions between inscribed texts and visual narratives in the decorative programme of the chapel of Sant'Isidoro. The first quote describes the engagement of the beholder with both images and texts as an act of viewing. The second passage, in turn, discusses the figurative representation of the translation of the body of St Mark in terms of a written (rather than visual) history. Taken together, these excerpts flout traditional oppositions between reading and viewing, and between textual and visual argumentation. Identifying both word and image as re-presentations, Canale asserts their convergence as means of cognition and historical certification, stimulating us to consider inscriptions and images in the chapel of Sant'Isidoro as a unified semantic ensemble. He also highlights the ability of written words to act on their viewers by means of non-verbal elements as much as through their textual content, encouraging specific reflections about the visual properties of inscriptions in the chapel of Sant'Isidoro.

Besides attending to the correlations between written and visual history, Canale explicitly invites his readers to verify the reliability of his chronicle against the façade of San Marco, pointing to the basilica not only as a memorial to Venetian achievements, but also-crucially-as an authoritative historical source. Based on this consideration, can we approach the chapel of Sant'Isidoro, too, as a source of factual certification-and, if so, what historical realities were its inscriptions intended to validate? In this perspective, it is worth remembering that Canale's Histories were written between 1267 and 1275, chronologically overlapping with the ambitious redecoration

14 Canale 1972, 155. This and the following passage have been translated and eloquently discussed in relation to Venetian historical painting in Fortini Brown 1988, 80f.

15 Canale 1972, $20 f$. 


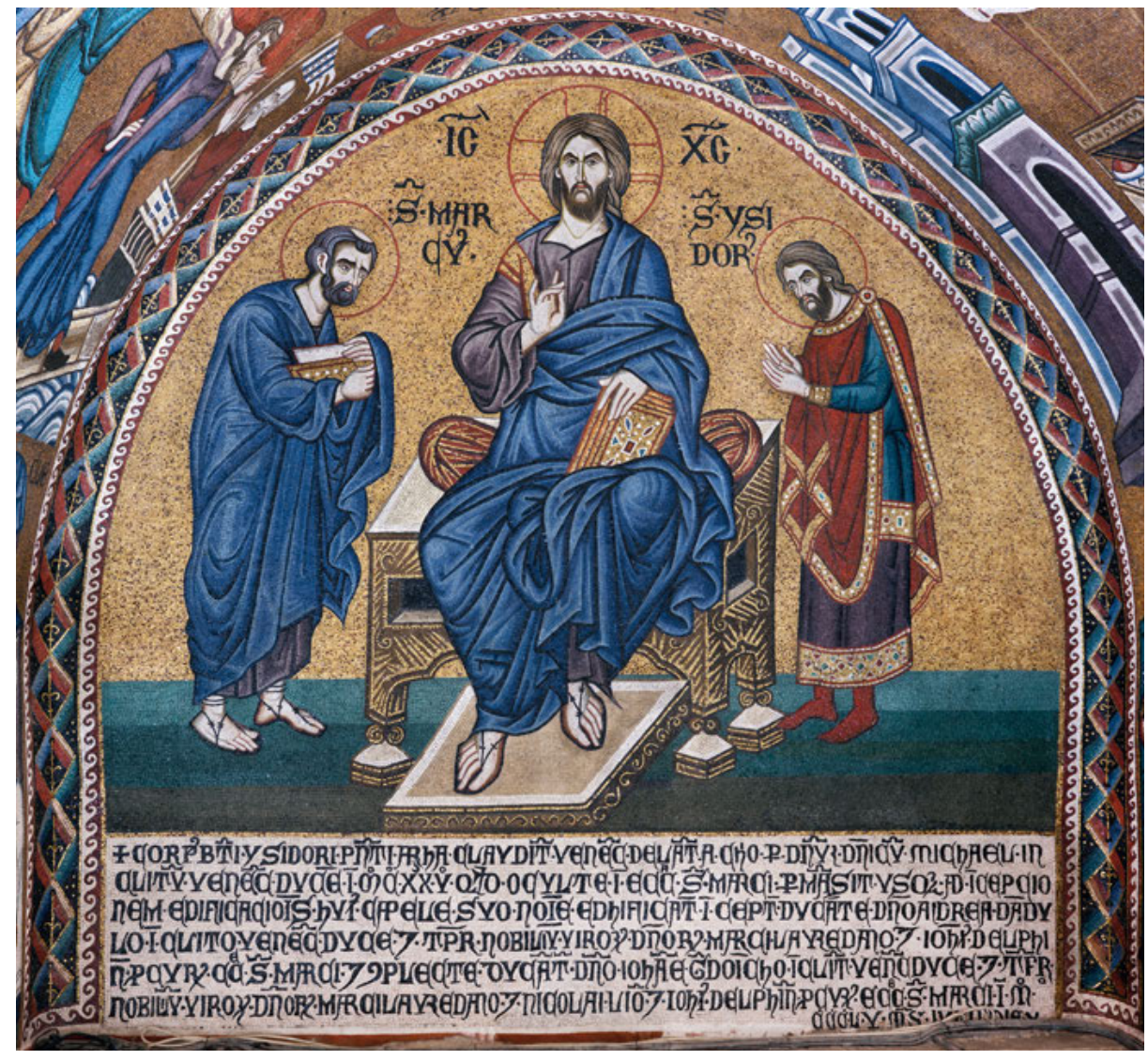

Fig. 5: Venice, San Marco, Chapel of Sant'Isidoro, east wall lunette.

of the western façade of San Marco that took place in the decades following the Fourth Crusade. ${ }^{16}$ Like the new façade, Canale's chronicle celebrated Venice's prestige and past achievements. However, the campaign of redecoration of San Marco was likely begun soon after the conquest of Constantinople by Latin and Venetian crusaders in 1204, at the peak of Venice's international success. In contrast, Canale wrote the Histories at times of great anxiety, when Venice's hegemony overseas was threatened by the rise of a rival sea power, Genoa, and by the recapture of Constantinople by the Byzantines after half a century of Latin and Venetian occupation. ${ }^{17}$ Geopolitical and institutional instability, and the ensuing need to give firmer justification to Venice's international claims, also acted as potent stimuli for the production of visual and textual histories in the mid-Trecento. Andrea Dandolo's Chronica Extensa was finished

16 Limentani 1974.

17 Nicol 1988, 176-198; see also Perry 2015, 158f. 


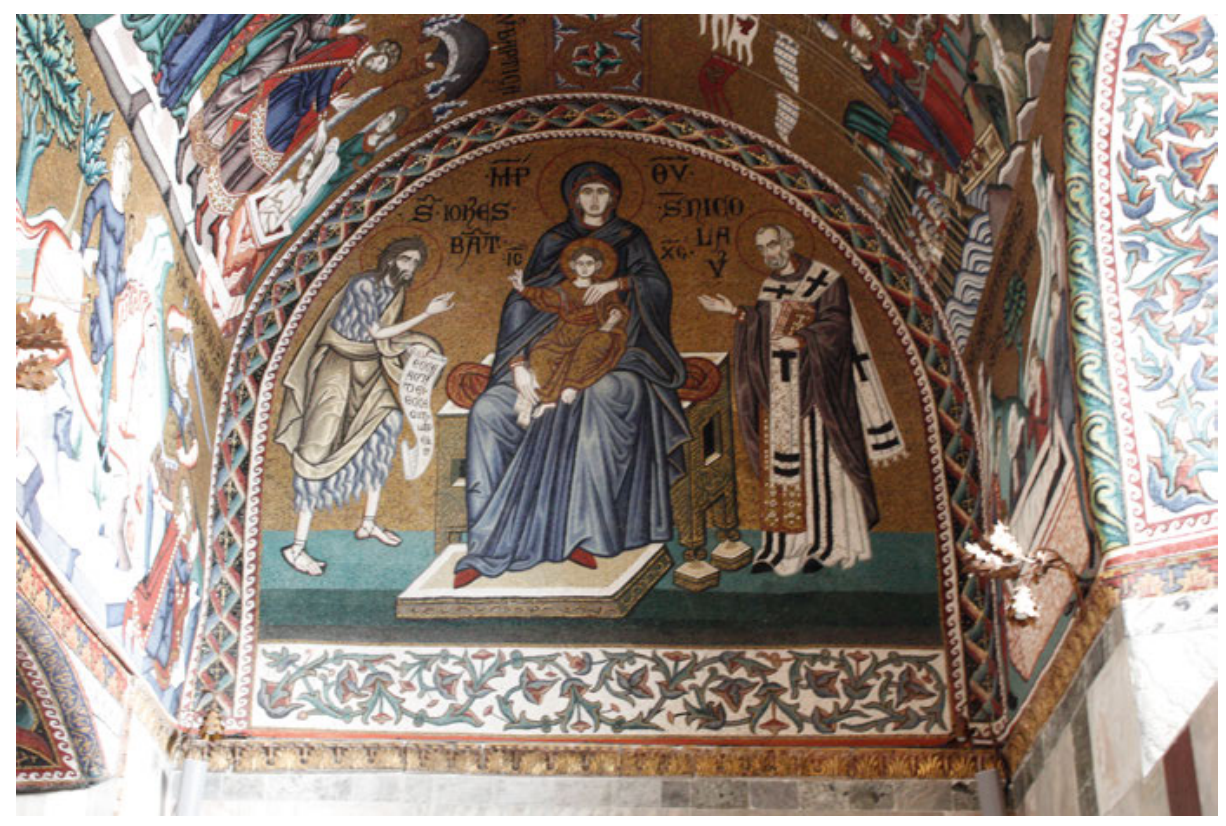

Fig. 6: Venice, San Marco, Chapel of Sant'Isidoro, west wall lunette.

in 1352, and the chapel of Sant'Isidoro followed soon after, in $1355 .{ }^{18}$ Roughly concomitant, both artistic endeavours memorialized Venice's successes overseas just as Venice's hegemony and stability were imperilled by a new bout of war against Genoa between 1350-55, and by internal political tensions. Historical narrative may have offered a useful means to impose conceptual order on reality at times of increased uncertainty. However, by inscribing present insecurities and challenges within a trajectory of long-term success, Dandolo's chronicle and the imagery and inscriptions in the chapel of Sant'Isidoro also gave historical grounding to the city's claims to international leadership, thus functioning as powerful agents of political orientation and of stabilization at times of change.

Finally, Canale's Histories trigger reflections about literacy, multilingualism and language choice that are crucial to our understanding of the epigraphic apparatus of the chapel of Sant'Isidoro. The Histories were written in French, the language most commonly spoken (and written) by western merchants, travellers and diplomats in the eastern Mediterranean. ${ }^{19}$ Although Venetian merchants were familiar with French, this was not the only, or primary language of the city. ${ }^{20}$ Foreign visitors presumably

18 Bellemo 1912, 257.

19 Baffi 2003; Catel 1937-38, and Catel 1939-40.

20 On the linguistic identity of medieval Venice, see Ferguson 2013; and Folena 1990, for the languages of Venetian overseas territories. 
spoke and wrote the language of their countries of origin with fellow nationals, but more permanent alien residents also spoke and wrote in the Venetian vernacular. ${ }^{21}$ By the mid-fourteenth century, Venetian vernacular was the standard language of oral communication, and was also widely employed in private correspondence and record-keeping. ${ }^{22}$ In addition, it is amply attested in Venetian inscriptions, particularly those commissioned by lay confraternities. ${ }^{23}$ Against the linguistic diversity of late medieval Venice, the choice of Latin in the chapel of Sant'Isidoro deserves specific attention, as it might have informed the semantic scope of its inscriptions, and coeval perceptions about their authority.

\section{Inscribing History}

These considerations add depth and complexity to our understanding of the inscriptions of the chapel of Sant'Isidoro, particularly the dedicatory epigraph on the east wall. Its layout and formal properties identify the epigraph as an authoritative text, and single it out from the numerous captions and tituli on the chapel's vault. These are written in black characters against golden background, and are positioned within the same pictorial space as the figurative episodes that they refer to. Within this space, images and words explicate each other-amplifying their relative significance, but also delimiting the place of narrative as contiguous to, but separate from, the space and time of the viewer. By contrast, the dedicatory inscription is conspicuously placed on the east wall of the chapel, and isolated from the figurative mosaics that surround it by means of a frame. Traced in black tesserae against a white background, the epigraph stands out against its richly coloured surroundings. Such visual contrast would be further enhanced by artificial lighting, which is likely to have been more intense near the altar area, drawing the viewer in, and inviting further analysis of the interplays between the dedicatory text, the architectural space and its overall visual and textual programme. The inscription, which is highly visible and legible, is written in gothic majuscule letters, and distributed over six lines, with the date of completion spilling over onto the seventh. Lines are separated by regular interlinear spacing, and single midline points divide individual words, facilitating the process of reading. ${ }^{24}$ Line breaks often fall mid-word, and standard abbreviations (both in the form of contractions and suspensions) and ligatures are used generously, perhaps suggesting efforts to maximise the number of characters in each line. The epigraph is located above St Isidore's tomb, and just below the imposing representation of

21 Tomasin 2016.

22 Tomasin 2016, and Hyde 1979.

23 Stussi 1997; and Ferguson 2013, 67-134.

24 On the development of punctuation in the middle ages and on its significance, see Parkes 1992. 
Christ in majesty between the saints Isidore and Mark. The presence of Isidore's body and effigy, as well as the figures of Christ and Mark, lend credibility and authority to the inscription, simultaneously verifying and sanctifying its contents. In turn, the inscription visually unites the tomb of the martyr with his figurative representation on the east wall, activating a process of mutual reinforcement and validation between sculptural ensemble, visual imagery and text.

Latin, the official language of the Church, was ubiquitous in religious settings across western Europe, and its epigraphic use in the chapel of Sant'Isidoro is unsurprising. However, in this particular context, it might also have helped to advertise the associations between the inscription and the Venetian government. Vernacular had made its appearance in state documents in the early thirteenth century, when diplomatic tracts originally written in foreign languages began to be sporadically translated into Venetian for reasons of convenience. Vernacular translations of Venice's statutes, and of the capitolari (regulations) of a variety of lower state magistracies, have also survived from as early as the fourteenth century. However, these volgarizzazioni were produced outside the official limits of the ducal chancery. Instead, Latin continued to dominate the written communications of the Venetian government, and specifically of the doge, until the fifteenth century. ${ }^{25}$ Notwithstanding Venice's linguistic diversity and the rising importance of vernacular as a written language in the fourteenth century, Latin thus remained the chief language of law and power. As such, it might have been deployed in the chapel of Sant'Isidoro to further corroborate the authority of its inscriptions, rendering incontestable the hagiographical and historical account that they provided.

David Perry has recently reminded us that accounts of relic translation performed a fundamental civic role in Venice. ${ }^{26}$ The identity of the city was predicated on possession of the body of Saint Mark and on accounts of its legendary translatio from Alexandria in the ninth century. Based on this precedent, other translatio accounts, which traced the trajectory of a relic's voyage to the lagoon and celebrated its installation in the city, were deployed to advertise the magnitude of Venetian networks of influence, whether actual or symbolic. The translatio sancti Marci was expanded and altered over the centuries to reflect new religious and political concerns, and the same happened to other narratives of translation, which were developed and modified over time in response to novel civic preoccupations. This was the case for St Isidore, whose increased popularity in the lagoon in the mid-Trecento is an eloquent example of how sacred history was manipulated in Venice to underscore contemporary anxieties and political agendas. In turn, the building of a new chapel in his honour testifies to the

25 On the uses of vernacular in official and quasi-official Venetian written documents in the thirteenth and fourteenth century, see Tomasin 2001, 11-58.

26 Perry 2015, is entirely dedicated to this subject. 
crucial part that public imaging and writing played in the production and dissemination of collective memories and shared visions of history.

St Isidore's original resting place was the Aegean island of Chios, possession of which was the object of fierce contentions between Venice and Genoa throughout the middle ages. In the 1350s, when Andrea Dandolo 're-invented' the body of St Isidore of Chios in the basilica of San Marco, the island was a key Genoese stronghold in the eastern Mediterranean, whence the city conducted military and commercial raids against Venice and its colonies. ${ }^{27}$ Claiming ownership of the body of Isidore at times of violent confrontations with Genoa, Venice not only claimed the favour and protection of yet another saint, but also implicitly challenged the legitimacy of Genoese authority over Chios and-by extension-over the eastern Mediterranean. ${ }^{28}$

As discussed by Michele Tomasi, the cult of St Isidore was unattested in Venice before the fourteenth century, indirectly confirming the correlation between the saint's renewed popularity and the Veneto-Genoese wars. Paolino Veneto (d. 1344) and Andrea Dandolo, both writing in the central decades of the century, were the first Venetian historians to mention the translation of Isidore's body to Venice in 1125. ${ }^{29}$ The earliest surviving manuscript account of this event (purportedly written by eye-witness Cerbano Cerbani in the twelfth century) dates from the mid-Trecento. Finally, the earliest Venetian liturgical books that commemorate the saint's translation to Venice date from the 1370s, after the completion of his new shrine at San Marco. ${ }^{30}$ In this context, the significance of the textual and visual apparatus of the chapel of Sant'Isidoro in constructing and disseminating the image of the saint, and in sustaining his connections to Venice against Genoa, can hardly be overestimated.

The scenes of Isidore's translatio, depicted on the north side of the vault, cluster towards the east end of the chapel, nearest the saint's tomb, simultaneously proving Isidore's presence and marshalling authority through it. The descriptive captions above these episodes are significantly longer than those accompanying the scenes of Isidore's life and martyrdom, indicating that the latter part of the story-which certified the legitimacy of Venice's acquisition of the holy body, and, by extension, the priority of the city's military claims over Chios-wielded greater evidentiary power. ${ }^{31}$ Further confirming his actual presence in Venice and his benevolence towards the city, St Isidore was represented next to Christ and Mark in the east wall lunette.

27 Perry 2015, 172-174.

28 This was also noted by Tomasi 2008, 20; and Goffen 1994.

29 Paolino Veneto (c. 1270-1344), also known as Paolino Minorita, mentions the event in his Historia Satyrica. His work has not been published, but see, for a manuscript example, Biblioteca Apostolica Vaticana, Vat. Lat. 1960, fol.233r. I am very grateful to Marco Petoletti for sharing his transcription of Paolino's account from the Vatican manuscript. Based on Paolino, Andrea Dandolo also describes the translatio: Dandolo 1942, 22 and 234f.

30 For a detailed discussion of sources, and further bibliography, see Tomasi 2008, 17.

31 The different length of the mosaic captions was also explained by Tomasi 2008, 18, in relation to the greater importance of Isidore's translatio over other episodes from his life. 
Adding military overtones to the narrative, moreover, Doge Domenico Michiel is represented in the mosaics of the vault as a military leader, followed by armed soldiers who carry the standards with the winged lion of St Mark, the symbol of Venetian dominion abroad..$^{32}$

Public writing and imaging in the chapel of Sant'Isidoro visualised a partisan narrative that sanctioned the saint's association with Venice, and demonstrated the religious piety of the Venetians, their military prowess, and the legitimacy and longevity of their presence in the Mediterranean in an age of fierce conflict and dramatic uncertainty. As such, the mosaics participated in a sophisticated discourse of political legitimation that relied on the simultaneous construction of religious memory, historical narrative and juridical evidence, and on their convergence. This process, in turn, rested upon a constellation of interrelated sources, orchestrated by the government of Venice. Andrea Dandolo's chronicle, a wide-ranging historical work that celebrated Venice's achievements and indirectly warranted the legitimacy of its political regime and its claims overseas, was physically produced in the ducal chancery. When it reached completion in 1352, the text was officially presented to the Great Council with a preface by the Great Chancellor, Benintendi Ravegnani, confirming the public character of the work. The decoration of the chapel of Sant'Isidoro overlapped with the composition of the Chronica Extensa, and both were preceded by substantial activities of legal systematization. Just after his election as doge in 1343, Andrea Dandolo established a committee for the revision of the city statutes, which had first been codified by Jacopo Tiepolo in $1242 .{ }^{33}$ As soon as this task was accomplished in 1346, the doge charged the chancery with collecting Venice's foreign treaties into two comprehensive registers: the liber albus, comprising Venetian pacts with eastern polities; and the liber blancus, containing treatises with the Italian mainland. ${ }^{34}$ These provisions represented an important change for the political and legal system of the city: Venice oscillated during the middle ages between a system based on jurisprudence and driven by legal practice (what we would now call Common law), and one based on codified legislation (what we would now identify as civil law). Reinforcing and expanding the corpus of codified laws, Dandolo accelerated the conversion of the legal system of the city from the former to the latter model..$^{35}$ In addition, such activity of legal systematisation provides compelling evidence of the increasing sensitivity of Venetian authorities to the power of the written word, and to its ability to store juridical evidence and build political legitimacy.

These different means of public and political enunciation-historical writing, legal codification, monumental epigraphy and imagery-covered much of the same ground, and there existed between them a system of reciprocal validation and

32 For a visual comparison, see Biblioteca Apostolica Vaticana, Bibl. Vat. 1960, fol. 233v.

33 Cessi 1938.

34 The table of contents of the two codices are published in Tafel and Thomas 1855.

35 Cracco 1976, especially 243. 
reinforcement. Archival documents provided Dandolo's historical work with factual basis and conceptual force. In turn, his chronicle gave those documents meaning, by integrating them within a comprehensive narrative of Venice's past that both framed and justified the city's present ambitions. The textual and visual programmes of the chapel of Sant'Isidoro were pivotal to this complex, intermedial discourse. At one level, they performed an evidentiary function, publicizing events that had already happened, and recording information that was available elsewhere, in Dandolo's chronicle and in the textual records of the chancery. However, as Martino da Canale stated in his Histories, the basilica of San Marco was understood by medieval viewers as the ultimate, incontrovertible archive of Venetian historical memory. In this context, the images and inscriptions in the chapel of Sant'Isidoro did not merely record the past, but gave it visual and material substance. Engaging with archival and historical practices, they proved that Isidore was really present in San Marco, that Venice's acquisition of his body was lawful, and, by extension, that the city's claims overseas enjoyed divine favour.

\section{Writing Politics}

The ability of inscriptions in San Marco to validate historical truths, and to mobilize them in the service of specific political ideas at times of change, provides a useful interpretative framework for another unusual element in the dedicatory inscription on the east wall of the chapel of Sant'Isidoro. The epigraph bears the names of three Venetian doges: Domenico Michiel (r.1116-29), Andrea Dandolo (r.1343-54) and Giovanni Gradenigo (r.1355-56). Engraving the names of individual and/or institutional patrons was standard practice in late medieval Italy. However, this was not the case in the church of San Marco. Here, the personal names of doges had never been monumentally memorialized before, except on their tombs. Ducal effigies, including those on the upper wall of the chapel of San Clemente, above the portal of Sant'Alipio, and in the Apparitio and Inventio scenes on the west wall of the south transept, were exclusively identified by the impersonal titulus 'dux' ${ }^{36}$ The reluctance to display the personal names of rulers in San Marco was deeply rooted in Venetian political ideology. Although they were honoured with many of the symbolic attributes of royalty, and though they held their office for life, Venetian doges remained magistrates, elected by the government. As such, they lacked the actual powers and

36 A partial exception to the rule of ducal anonymity is the twelfth-century inscription that commemorates the decoration of the lower registers of the chapel of St Clement, in San Marco, with marble panels during the dogate of Vitale Michiel. However, unlike the epigraphs in the chapel of St Isidore, this inscription was not publicly accessible and visible. See Hubach 1996, 373. 
prerogatives of kingship; ${ }^{37}$ and their representations in San Marco accordingly visualised an (impersonal) office, rather than the identity of an individual.

Recording the personal names of three doges, the inscription in the chapel of Sant'Isidoro marked a break from the tradition of ducal anonymity in San Marco that could hardly be unintentional, and that imbued the space of the chapel with ducal presence and an extra layer of political overtones. Andrea Dandolo had already experimented with inscribing ducal history in the basilica, albeit on a smaller scale. In 1343-45 he commissioned a thorough refurbishment of the Pala d'Oro, the Byzantine altarpiece that decorated the main altar of San Marco since the eleventh century (Fig. 7). ${ }^{38}$ The exact extent of Dandolo's renovations is unclear. ${ }^{39}$ However, we do know that the enamels in the lower register were re-arranged on this occasion to make space for a lengthy dedicatory inscription, engraved on two rectangular plaques (Fig. 8) ${ }^{40}$ This inscription is much smaller and significantly less visible than

37 Literature on this subject is vast. For a brief but accurate account of the progressive limitations imposed on ducal authority during the middle ages, see Crouzet-Pavan 2002, 195-210; an excellent discussion of the ducal images in the chapel of San Clemente is found in Hubach 1996.

38 A document dated 30 May 1343 confirms that the project benefited from a public subsidy of 400 ducats: Archivio di Stato di Venezia, Maggior Consiglio, Spiritus, 129v, cited in Gallo 1967, 177. The date of completion of Dandolo's renovation is inscribed on the Pala d'Oro itself, along with its earlier history as it was understood in the fourteenth century. See also Dandolo's references in his chronicle: Dandolo 1942, 180, 225 and 284.

39 For competing explanations of the material history of the Pala d'Oro, see Hahnloser/Polacco 1994; English Frazer 1982; Buckton/Osborne 2000.

40 The inscription is edited in Hahnloser/Polacco 1994, 9:

$\begin{array}{ll}\text { ANNO MILLENO CEN } & \text { POST QUADRAGEN/ } \\ \text { TENO IUNGITO QUI[N]/ } & \text { O QUINTO POST MI/ } \\ \text { TO TU[N]C ORDELAFV[S] } & \text { LLE TRECENTOS DA[N]/ } \\ \text { FALEDRU[S] IN URBE DU/ } & \text { DUL[US] ANDREAS PR[E]CLA/ } \\ \text { CABAT H[EC] NOVA F[A]C[T]A } & \text { R[US] HONORE DUCABA/ } \\ \text { FUIT GEMIS DITIS/ } & \text { T NOB[I]LIB[US]Q[UE] VIRIS } \\ \text { SIMA PALA Q[UE] RENO/ } & \text { TUNC P[RO]CURA[N]TIB[US] AL/ } \\ \text { VATA FUIT TE PET/ } & \text { MA[M] ECCL[ESI]AM MARCI V/ } \\ \text { RE DUCANTE ZIANI } & \text { ENERA[N]DA[M] IURE BE/ } \\ \text { ET PROCURABAT } & \text { ATI D[E] LAUREDANIS } \\ \text { TUNC ANGEL[US] ACTA } & \text { MARCO FRESCOQ[UE] Q[U]I/ } \\ \text { FALEDR[US] ANNO MILL/ } & \text { RINO TUNC VETUS } \\ \text { ENO BIS CENTENO/ } & \text { HEC PALA GEMIS } \\ \text { Q[UE] NOVENO. } & \text { P[RE]CIOSA NOVATUR. }\end{array}$

It may be translated into English as follows:

In the year 1125, when Ordelaffo Falier was the doge of the city, this altarpiece, so rich in precious stones, was first made; it was (then) renovated, when you, Pietro Ziani, were doge, and at the time Angelo Falier was the procurator, in 1209. // Subsequently, in 1345, the most highly esteemed Andrea Dandolo was doge, and when the noble men Marco Loredan and Francesco Querini were procurators of the venerable mother church of San Marco, rightly blessed, then this ancient altarpiece was renewed with precious gemstones. 


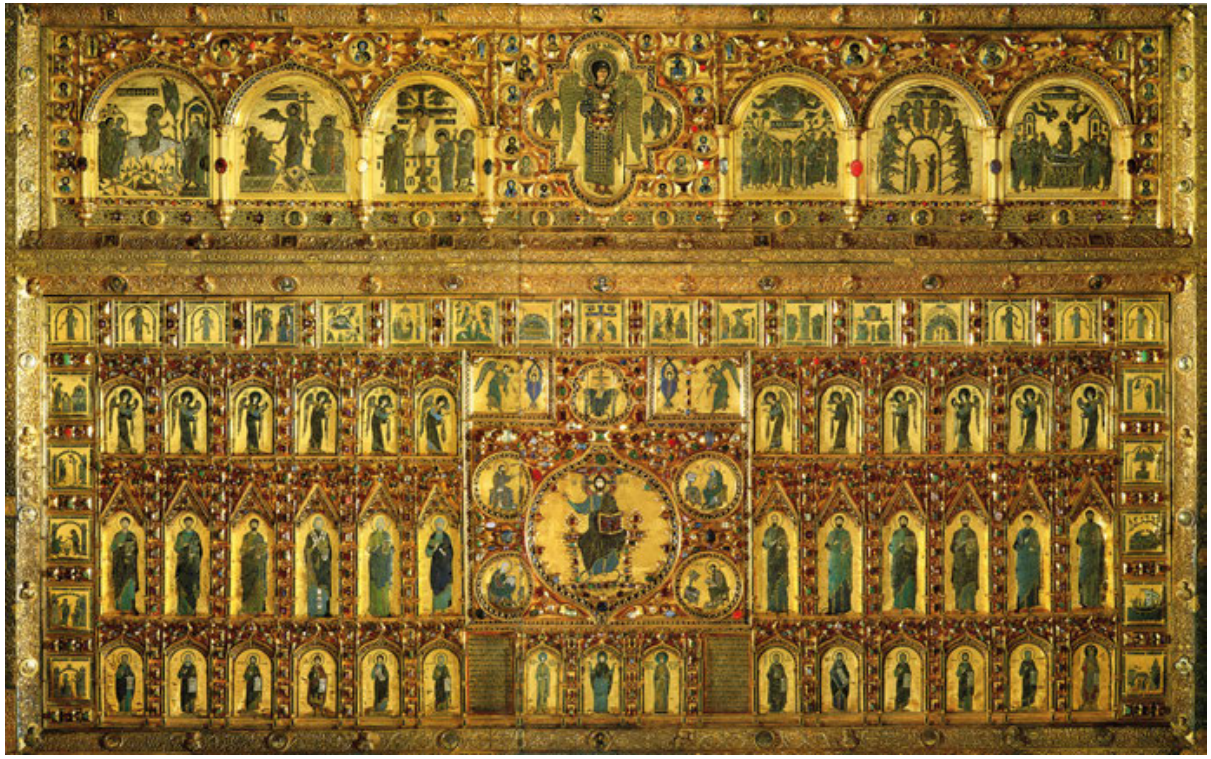

Fig.7: Venice, San Marco, Pala d'Oro, Byzantine work, eleventh-fourteenth century.

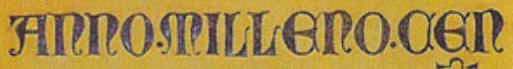
TERO-IVRGITO.OVI TO:TÜG.ORDEL 'ARV. FHLEDRV.IRTRBE.DV

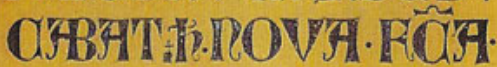
FVIT. GEMIS.OITIS SIRYH.PHLA:Ö:RERO JHTTH.PVIT:TE.PET RE.DVAHTT G.CIITI. GT.PROCVRABHT: TVRA:HGEL:HCTH. HFLEDR:FTRO.JPILLS eno.bis.centero oznodero $\because$ ? posm. OVADRAGER O. ovmeTo.POSTIMI LiLG:TR8CGIRTOS:DA DVL:AMDREAS.PZCLA R:LONOZG- DVVOFIBA THROBHIB? O2UIRIS.

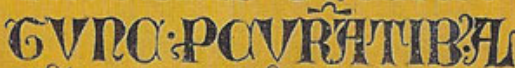

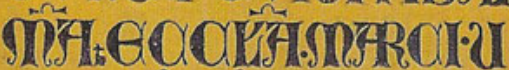
EILERTIDFAIVRE.BG

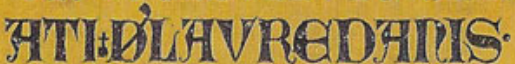
MNRCO.FRESCOOOSOI RIROATVRCIIGTVS hEG.PHLF. GEITIS. PCIOSH-ROV'HTUR.

Fig. 8: Venice, San Marco, Pala d'Oro, inscription, 1345. 
the dedicatory epigraph in the chapel of Sant'Isidoro. Nevertheless, it shares some key features with it. It is placed in a symbolically prominent position, on the high altar of the church, and right below an enamelled representation of Christ in majesty. The text is clearly written in gothic majuscule, and neatly arranged in black characters on two gilded sheets. The regular, rectangular shape and plain background of the metal supports evoke the pages of a book or a charter, signalling-just like the dedicatory text in the chapel of Sant'Isidoro-the convergence between documentary culture, epigraphy and history making in Venice at this time. The Pala d'Oro, too, brings together the distant past of Venice and its current history, celebrating the object's initial creation by doge Ordelaffo Falier in 1105, and its subsequent modifications by doge Pietro Ziani (in 1209), and under Dandolo himself in 1345. As was the case with Isidore's translatio, the history of the altarpiece is virtually undocumented prior to the mid-fourteenth century, and makes its first appearance in Andrea Dandolo's chronicle. In addition, in a way similar to the dedicatory inscription in the chapel of Sant'Isidoro, the epigraph on the Pala d'Oro recapitulates the history of the artefact in connection with three doges, one of whom (Ordelaffo Falier) is also represented visually, next to the epigraph. ${ }^{41}$

Debra Pincus compellingly interpreted the prominence of ducal representations in Dandolo's artistic commissions as a reflection of his attempt to promote a new attitude towards the doge, whose role was reformulated during the Trecento as that of a sacral figure and a visionary of the divine plan, and one who embodied God's special relationship with the city of Venice and brought divine revelation into the deliberations of state. ${ }^{42}$ However, such growing emphasis on the symbolic significance of the doge was counterbalanced in the fourteenth century by increasing limitations on his actual power. ${ }^{43}$ The dedicatory inscriptions on the Pala d'Oro and in the chapel of Sant'Isidoro manifest these underlying tensions. The two texts spell out the personal names of doges, and record them within the revered (and politically charged) space of San Marco in a durable form. Doing so, they foreground ducal authority in a way that was unprecedented in San Marco, setting specific examples of ducal virtue and emphasizing the significance of doges as emblems of the Venetian state. However, the two artworks supplement such ducal references with the names of the procurators of San Marco, secular officers chosen by the Great Council among the Venetian nobility to administer the basilica and ensure its upkeep. This addition is highly meaningful. The mosaic and enamel inscriptions cast the two artistic commissions

\footnotetext{
41 The enamel depicting Ordelaffo Falier, was modified at an unspecified time. The nature and extent of the alteration have been the objects of much scholarly discussion. See Buckton/Osborne 2000, with further references.

42 Pincus 2000.

43 Compelling evidence of this process is provided by the texts of the ducal oath of office (promissio), repeatedly modified during the thirteenth and fourteenth centuries to restrict the doge's power. See Musatti 1888; and Cecchetti 1864, 97-129.
} 
as collaborative, institutional projects, rather than as mere ducal memorials. In doing so, they also reiterate the collective nature of Venetian political authority, guarding it against (potentially unwarranted) ducal pretensions, and emphasising the role of the basilica of San Marco as a material archive of Venetian shared memory.

\section{The Sound of Silence}

So far, this essay has concentrated on what there is to see and read in the inscriptions and visual programme of the chapel. However, in his study of practices of erasure in the monumental inscriptions of medieval Tunisia, Jonathan Bloom advised that examining what exists-what inscriptions say, and how they visually display it-is only half the task. Our knowledge of what 'should' exist and is missing is equally important, for it may further our understanding of what has vanished from the historical record, and why. ${ }^{44}$ The inscription in the chapel of Sant'Isidoro is an ideal case study in the political implications of the unwritten. As already mentioned, Andrea Dandolo ruled between 1343 and 1354, while Giovanni Gradenigo was only elected on 21 April 1355. The list of doges memorialized in the dedicatory inscription is therefore incomplete: the missing name is that of doge Marino Falier, elected on 11 September 1354, shortly after Andrea Dandolo's death. Falier's dogate was brief and painful. Following his failed attempt to overturn the oligarchic government of the city, he was the first and only doge in the history of Venice to be publicly executed, and died on the monumental stairs of the ducal palace, the very same spot where he had pledged loyalty to the Venetian State a few months prior. ${ }^{45}$ The conspiracy generated huge tumult in Venice, and the doge's violent death became an enduring symbol of the exemplary punishment that befell traitors of the Venetian republic, and a powerful reminder of the limits of ducal authority. ${ }^{46}$

This dark episode of Venetian political history is highly significant for our understanding of how the chapel of Sant'Isidoro and its textual programme would be seen and understood by coeval viewers. Marino Falier's conspiracy was discovered on 16 April 1355, feast-day of the translatio of St Isidore. The doge and the leaders of the coup were executed the next day, while several of their accomplices were sentenced to death or life imprisonment over the following weeks. ${ }^{47}$ In May, when the memory

44 Bloom 2015, esp. 73.

45 Lazzarini 1897; Ravegnani 2017, 75-134.

46 The sentiment of contemporaries towards the conspiracy is eloquently encapsulated in a letter written by Petrarch shortly after the events: “To all future doges, I say: always bear this in mind, and learn from these events that doges are dukes, not lords; actually, that they are not even dukes, but honourable servants of the republic", Petrarca/Fracassetti 1866, vol.4, 191. The English translation is by the present author.

47 Caresini 1923, 9f.; Lazzarini 1897, 104-107, with further references. 
of the dramatic event was still vivid, and as the chapel of Sant'Isidoro neared completion, the government instituted an annual ceremony to commemorate the foiling of the plot. Each year, on the feast-day of St Isidore, the doge, government, and major confraternities formed a procession that circled around Piazza San Marco and entered the basilica, where a solemn mass was celebrated. ${ }^{48}$ Although the original deliberation does not explicitly mention Sant'Isidoro's chapel, it seems inevitable that the shrine would be involved in the rituals of the day, as is also confirmed by later sources. In his account of the life of Doge Francesco Foscari (r.1423-57), Marin Sanudo the Younger explicitly indicates that the doge attended mass in the chapel of Sant'Isidoro on 16 April. ${ }^{49}$ Other Renaissance and early modern sources describe the procession in some detail. The ducal cortege, wearing black, entered the basilica through the central portal. Once inside the church, the doge visited St Isidore's shrine, where he knelt to gain the indulgence ( $a$ prender il perdono). Following this ritual act of penance, the doge moved to the choir of the church, where he attended mass, before the procession reformed, leaving San Marco from the central portal. ${ }^{50}$ The conspiracy, and the rituals through which it was subsequently commemorated and exorcised, are likely to have affected the ways in which coeval viewers saw and understood the chapel of Sant'Isidoro and its epigraphy, projecting further meanings onto them.

Dated 10 July 1355, the dedicatory epigraph on the east wall captures the state of affairs of the Venetian government in the aftermath of Marino Falier's death. The disgraced doge is-understandably-omitted from the inscription, which memorializes instead his successor, Giovanni Gradenigo. In addition, the epigraph celebrates the name of Nicolò Lion, the Venetian aristocrat who had alerted the Venetian government to Falier's conspiracy, and was subsequently rewarded for his loyalty with the prestigious appointment as procurator of San Marco. ${ }^{51}$ Whether the absence of Falier's name represented a deliberate omission or was due to the brevity of his office is difficult to establish. Nevertheless, it would probably be noticed by coeval Venetian viewers, who would interpret it in relation to the annual rituals of commemoration. The Venetian doges, who solemnly visited the chapel on 16 April each year, and the magistrates and members of the confraternities that took part in the solemn procession, would likely experience the chapel as a powerful visual reminder of the responsibilities that derived from power, and of the consequences of political tumult. In this

48 The Council's act is transcribed in Corner 1749, 109. See also Lazzarini 1897, 295f., with reference to further primary sources.

49 Sanudo 1999, 314.

50 For descriptions of the ceremonials held on 16 April, see Sansovino 1663, 510-511, and Biblioteca del Museo Civico Correr, Venezia, BMCVe, MS P.D. 517b, 'April' (folios not numbered). both also cited in Muir 1984, 250 and note 16 on page 278. See also Michiel (1829), vol. 3, 171-173. The procession appears to have still been held in the late eighteenth century, prior to the fall of the Republic. See Valerio 1787, note (a) on page 144 .

51 Ravegnani 2017, 122. 
context, the inscription, which celebrated an array of virtuous doges and procurators, but omitted Falier's name, might have fulfilled a dual function, both preserving ducal memory and enforcing sanctions against it. The provisions taken by the Venetian government indicate that Falier was the object of explicit and repeated iterations of public damnatio, which were achieved not only through the active destruction of textual or visual records, but also by means of textual silences and omissions. The report of the deliberations issued by the Council of the Ten in the year 1355 has survived. However, as scholars have noted, the page that should have recorded Falier's death sentence was deliberately left blank, following the cryptic phrase non scribatur: 'the matter will not be put down in writing' ${ }^{52}$ In 1366, eleven years after Falier's death, the memory of his conspiracy was still offensive enough for the Council of the Ten to have the doge's effigy removed from the gallery of official portraits set up in the ducal palace. Following the tradition of pitture infamanti, it was initially suggested that the portrait should be replaced with a new effigy of Marino Falier, depicted upside down and with his head half severed from the neck. This proposal was rejected, but the picture was nevertheless removed, together with the doge's coat of arms, and the empty space that it left on the wall was filled with plain blue paint, and inscribed in white letters Hic fuit locus ser Marini Faletro decapitati pro crimine proditionis, 'This used to be the place of Sir Marino Faliero, beheaded for his criminous betrayal. ${ }^{53}$ This memorial-by-omission was preserved even after the ducal palace was redecorated in the sixteenth century, following a devastating fire in 1577. The space next to Andrea Dandolo's portrait, painted by Domenico Tintoretto (1580-90), was filled with a fictive black veil, inscribed with the phrase Hic est locus Marini Faletro, decapitati pro criminibus. ${ }^{54}$ While the mosaics of the chapel of Sant'Isidoro do not refer to the disgraced doge, the ceremonials of regulated oblivion held on 16 April would encourage viewers to experience the shrine in relation to the overt repressions of his memory in other public spaces.

52 Lazzarini 1897, 5-8, who also suggests that the proceedings of the doge's trial were recorded more extensively in a different archival file.

53 The original documents with the two alternative suggestions are published in Lorenzi 1868, 38f. For a discussion, see Fortini Brown 1997. On Marino Faliero's damnatio memoriae, see also Ortalli 1979, $168 f$.

54 Ravegnani 1994, http://www.treccani.it/enciclopedia/marino-failier_(Dizionario-Biografico)/ (last accessed 14 November 2016). 


\section{Conclusions}

Following a well-established Venetian tradition, the chapel of Sant'Isidoro merged hagiography, history and institutional memory to promote the city's legitimacy and prestige on the international stage in the face of difficulties, and to project messages of political stability at times of domestic unrest. Monumental writing was pivotal to this agenda, as was its interaction-both visual and textual-with pictorial representations, historical and archival practices, and civic ceremonial.

At one level, the inscriptions in the chapel of Sant'Isidoro performed a declarative and narrative function. They both complemented and sustained the imagery on the vault and walls, providing a textual gloss to the visual account of the wondrous invention and translation of the saint's body to the lagoon, and certifying it. The dedicatory inscription on the east wall also informed viewers' experience of the chapel. Made of mosaic, but written in black characters on white background, this inscription was visually distinct from the colourful narrative episodes surrounding it, and evoked the appearance-and the authority-of written documents or stone epigraphs instead. Moreover, the conspicuous position of the epigraph between Isidore's tomb and the representation of Christ in majesty between saints Mark and Isidore, emphasised the significance of the written word in mediating medieval experiences of the sacred.

Memorializing the names of virtuous doges and procurators, and making them permanently visible in the sacred space of San Marco, this epigraph also signals a noteworthy transformation in the mechanics of institutional validation in Venice, pointing to the rising role of the written word and of public advertisements as providers of juridical evidence and as guarantors of political legitimacy. Finally, the annual commemorations of Marino Falier's defeat engaged the epigraph in a ritual of public condemnation and exorcism that both confirms and complicates Martino da Canale's statements about the role of images and inscriptions in San Marco. They were durable, material archives upon which public Venetian memory was in-scribed, verified and preserved. Nevertheless, they also represented sites of memory-sanction and obliteration, where more uncomfortable leftovers of history could be overwritten, written out or reframed, instructing the Venetian community not only what to remember, but also how to forget. 


\section{Bibliography}

Andaloro, Maria/ Demus, Otto (eds.) (1990), San Marco, Basilica Patriarcale in Venezia, 2 vols. Milan.

Arnaldi, Girolamo (1970), “Andrea Dandolo Doge-Cronista”, in: Agostino Pertusi (ed.), La Storiografia Veneziana fino al secolo XVI. Aspetti e problemi, Florence, 127-268.

Baffi, Sandro (2003), "Martino da Canale: motivations politiques et choix linguistiques", in: François Livi (ed.), De Marco Polo à Savinio. Ecrivains Italiens en Langue Française, Paris, 35-46.

Balard, Michel (1997), "La Lotta Contro Genova”, in: Giorgio Cracco, Girolamo Arnaldi, and Alberto Tenenti (eds.), Storia Di Venezia. Dalle Origini Alla Caduta, Vol. 3: La Formazione dello Stato Patrizio, 87-126. Rome. <http://www.treccani.it/enciclopedia/la-formazione-dello-statopatrizio-le-sfide-esterne-la-lotta-contro-genova_\%28Storia-di-Venezia\%29/> (last accessed 28.08.2017)

Bedos-Rezak, Brigitte Miriam / Hamburger, Jeffrey F. (eds.) (2016), Sign and Design. Script as Image in Cross-Cultural Perspective (300-1600 CE), Washington.

Bellemo, Vincenzo (1912), "La Vita e i Tempi di Benintendi De’ Ravagnani, Cancelliere Grande della Veneta Repubblica”, in: Archivio Veneto 23 (2), 237-284.

Bloom, Jonathan (2015), "Erasure and Memory: Aghlabid and Fatimid Inscriptions in North Africa", in: Antony Eastmond (ed.), Viewing Inscriptions in the Late Antique and Medieval World, Cambridge, 61-75.

Bourdieu, Pierre (1993), “Esprits d'État. Genèse et structure du champ bureaucratique”, in: Actes de la recherche en sciences sociales (96-97), 49-62.

Brunetti, Mario (1909). "Venezia durante la Peste del 1348" in: Ateneo Veneto 32, 289-311.

Buckton, David/ Osborne, John (2000), "The Enamel of Doge Ordelaffo Falier on the Pala d'Oro in Venice”, in: Gesta 39 (1), 43-49.

Canale, Martino da (1972), Les Estoires de Venise: Cronaca Veneziana in Lingua Francese dalle Origini al 1275, ed. by Alberto Limentani, Florence.

Caresini, Rafaino (1923), Raphayni de Caresinis Cancellarii Venetiarum Chronica aa. 1343-1388, ed. by Ester Pastorello (Rerum Italicarum Scriptores, vol.12/2), Bologna.

Catel, Paulette (1937-38), “Studi sulla Lingua della ‘Cronique des Veniciens”, in: Rendiconti dell'Istituto Lombardo di Scienze e Lettere, III, 2, 305-48.

Catel, Paulette (1939-40), "Studi sulla Lingua della “Cronique des Veniciens", in: Rendiconti dell'Istituto Lombardo di Scienze e Lettere, Series III, 4 (1939-40), 39-63.

Cecchetti, Bartolomeo (1864), Il Doge di Venezia, Venice.

Cessi, Roberto (1938) Gli Statuti Veneziani di Jacopo Tiepolo del 1242 e le loro Glosse, Venice.

Chojnacki, Stanley (1997), “La Formazione della Nobiltà dopo la Serrata”, in: Giorgio Cracco, Girolamo Arnaldi, and Alberto Tenenti (eds.), Storia di Venezia. Dalle Origini alla Caduta della Serenissima, Vol. 3: La Formazione dello Stato Patrizio, Rome, 641-725.

Corner, Flaminio (1749), Ecclesiae Venetae Antiquis Monumentis Nunc Etiam Primum Editis Illustratae Ac in Decades Distributae, vol.10, Venice.

Cracco, Giorgio (1967), Società e Stato nel Medioevo veneziano (secoli XII-XIV), Florence.

Cracco, Giorgio (1976), “La Cultura Giuridico-Politica nella Venezia della ‘Serrata”, in: Girolamo Arnaldi (ed.) Storia della Cultura Veneta, Vol. 2, Vicenza, 238-271.

Crouzet-Pavan, Elisabeth (2002), Venice Triumphant: the Horizons of a Myth, Baltimore.

Dandolo, Andrea (1942), Chronica per Extensum Descripta: aa 46-1280 D.C., ed. by Ester Pastorello, (Rerum Italicarum Scriptores, Vol. 12 (1)), Bologna.

De Franceschi, Enzo (2003), “I Mosaici della Cappella di Sant'Isidoro nella Basilica di San Marco a Venezia”, in: Arte Veneta 60, 7-29. 
De Franceschi, Enzo (2008), “I Mosaici della Cappella di Sant'Isidoro nella Basilica di San Marco fra la Tradizione Bizantina e le Novità di Paolo Veneziano", in Zograf 32, 123-130.

De Franceschi, Enzo (2013), “Lo Spazio Figurato del Battistero Marciano a Venezia. Una Introduzione”, in: Ateneo Veneto, Serie Terza, 12 (1), 253-265.

Eastmond, Antony (ed.) (2015), Viewing Inscriptions in the Late Antique and Medieval World, Cambridge.

English Frazer, Margaret (1982), “The Pala d'Oro and the Cult of St. Mark in Venice”, in: Jahrbuch der Österreichischen Byzantinistik, 32 (5), 273-279.

Favreau, Robert (1989), “Fonctions des inscriptions au Moyen Âge”, in: Cahiers de Civilisation Médiévale 32 (127), 203-232.

Ferguson, Ronnie (2013), Saggi di Lingua e Cultura Veneta, Padua.

Folena, Gianfranco (1990), Culture e Lingue nel Veneto Medievale, Padua.

Fortini Brown, Patricia (1988), Venetian Narrative Painting in the Age of Carpaccio, New Haven.

Fortini Brown, Patricia (1997), “Committenza e Arte di Stato”, in: Giorgio Cracco, Girolamo Arnaldi, and Alberto Tenenti (eds.), Storia di Venezia. Dalle Origini alla Caduta della Serenissima, Vol. 3: La Formazione dello Stato Patrizio, 783-824, Roma.

Gallo, Rodolfo (1967), Il Tesoro di S. Marco e la sua Storia. Venice/Rome.

Goffen, Rona (1994), "Paolo Veneziano e Andrea Dandolo. Una Nuova Lettura della Pala Feriale” in: Hans R. Hahnloser / Renato Polacco (eds.) (1994), La Pala d'Oro, Venice, 173- 184.

Hahnloser, Hans R. / Polacco Renato (eds.) (1994), La Pala d'Oro, Venice.

Horn, Gabriele (1991), Das Baptisterium der Markuskirche in Venedig: Baugeschichte und Ausstattung, Frankfurt / New York.

Hubach, Hanns (1996), “Pontifices, Clerus - Populus, Dux. Osservazioni sul Significato e sullo Sfondo Storico della più Antica Raffigurazione della Società Veneziana”, in: Antonio Niero (ed.), San Marco: Aspetti Storici e Agiografici, Venice, 370-397.

Hyde, John Kenneth (1979), "Some Uses of Literacy in Venice and Florence in the Thirteenth and Fourteenth Centuries", in: Transactions of the Royal Historical Society 29, 109-128.

Katzenstein, Ranee (1987), Three Liturgical Manuscripts from San Marco: Art and Patronage in MidTrecento Venice (Ph.D. Diss., Harvard University), Harvard.

Klein, Holger A. (2010), “Refashioning Byzantium in Venice, ca. 1200-1400”, in: Robert S. Nelson and Henry Maguire (eds.), San Marco, Byzantium, and the Myths of Venice, Washington, 193-225.

La Cappella Di Sant'Isidoro (2008), Quaderni della Procuratoria. Arte, Storia, Restauri della Basilica di San Marco a Venezia, ed. by Irene Favaretto, Venice.

Lane, Frederic Chapin (1971), “The Enlargement of the Great Council of Venice”, in John Gordon Rowe (ed.), Florilegium Historiale. Essays Presented to W. K. Ferguson, Toronto, 237-274.

Lazzarini, Vittorio (1897), “Marino Faliero: La Congiura”, in: Nuovo Archivio Veneto 13, 5-108 and 277-374.

Lieb, Ludger (ed.) (2014ff.), Materiale Textkulturen [Material Text Cultures], 16 vols, Berlin/Boston.

Limentani, Alberto (1974), “Canal, Martino”, in: Dizionario Biografico Degli Italiani. Rome, <http:// www.treccani.it/enciclopedia/martino-canal_(Dizionario-Biografico)/> (last accessed 22.11.2017)

Lorenzi, Giambattista (1868), Monumenti per Servire alla Storia del Palazzo Ducale di Venezia; ovvero, Serie di Atti Pubblici dal 1253 al 1797, che Variamente lo Riguardano Tratti dai Veneti Archivii e Coordinati, Venice.

Marangon, Desi (2016), “Il Fascino delle Forme Greche a Venezia: Andrea Dandolo, l'arte e L'epigrafia", in: Hortus Artium Medievalium 22, 157-164.

Michiel, Giustina Renier (1829), Origine delle Feste Veneziane, 3 vols, Milan. 
Mostert, Marco / Adamska, Anna (eds.) (2014a), Writing and the Administration of Medieval Towns, Turnhout.

Mostert, Marco / Adamska, Anna (eds.) (2014b), Uses of the Written Word in Medieval Towns, Turnhout.

Muir, Edward (1984), Il Rituale Civico a Venezia nel Rinascimento, Rome 1984.

Musatti, Eugenio (1888), Storia della Promissione Ducale, Padua.

Nicol, Donald M. (1988), Byzantium and Venice: a Study in Diplomatic and Cultural Relations, Cambridge/ New York.

Ortalli, Gherardo (1979), “... Pingatur in Palatio ...”: La Pittura Infamante nei Secoli 13-16, Rome.

Parkes, Malcolm Beckwith (1992), Pause and Effect: an Introduction to the History of Punctuation in the West, Berkeley.

Perry, David M. (2015), Sacred Plunder: Venice and the Aftermath of the Fourth Crusade, University Park.

Petrarca, Francesco / Fracassetti, Giuseppe (1866), Lettere di Francesco Petrarca: delle Cose Familiari Libri Ventiquattro, vol. 4, Florence.

Petrucci, Armando (2002), Prima Lezione di Paleografia, Rome.

Pincus, Debra (1990), “Andrea Dandolo (1343-1354) and Visible History: The San Marco Projects", in: Charles M. Rosenberg (ed.), Art and Politics in Late Medieval and Early Renaissance Italy 1250-1500, Notre Dame, Indiana, 191-206.

Pincus, Debra (1996a), "Geografia e Politica nel Battistero di San Marco: la Cupola degli Apostoli”, in: Antonio Niero (ed.), San Marco. Aspetti Storici e Agiografici, Venice, 459-473.

Pincus, Debra (1996b), "The Stones of Venice in the Baptistery of San Marco", in: Cecil Lee Striker and James S. Ackerman (eds.), Architectural Studies in Memory of Richard Krautheimer, Mainz, 137-141.

Pincus, Debra (2000), “Hard Times and Ducal Radiance: Andrea Dandolo and the Construction of the Ruler in Fourteenth-Century Venice", in: John Jeffries Martin and Dennis Romano (eds.), Venice Reconsidered: The History and Civilization of an Italian City-State, 1297-1797, Venice, 89-136.

Pincus, Debra (2010), "Venice and its Doge in the Grand Design: Andrea Dandolo and the Fourteenth-Century Mosaics of the Baptistery", in: Robert S. Nelson and Henry Maguire (eds.), San Marco, Byzantium, and the Myths of Venice, Washington, 245-271.

Ravegnani, Giorgio (1986), “Dandolo, Andrea”, in: Dizionario Biografico Degli Italiani, Rome, <http:// www.treccani.it/enciclopedia/andrea-dandolo_\%28Dizionario-Biografico\%29/> (last accessed 20.08.2017).

Ravegnani, Giorgio (1994), 'Marino Failier’, in: Dizionario Biografico degli Italiani, Rome. <http:// www.treccani.it/enciclopedia/marino-failier_(Dizionario-Biografico)/> (last accessed 14.11.2016).

Ravegnani, Giorgio (2017), Il Traditore di Venezia. Vita di Marino Falier Doge, Bari.

Sansovino, Francesco (1663), Venetia Citta Nobilissima, Venice.

Sanudo, Marino (1999), Vite Dei Dogi (1423-1474), ed. by Angela Caracciolo Aricò. Vol. 1: 1423-1457, Venice.

Simonsfeld, Henry (1877), “Andrea Dandolo e le sue Opere Storiche”, in: Archivio Veneto 14, 49-149.

Stussi, Alfredo (1997), “Epigrafi Medievali in Volgare dell'Italia Settentrionale e della Toscana”, in: Claudio Ciociola (ed.), Visibile Parlare: le Scritture Esposte nei Volgari Italiani dal Medioevo al Rinascimento, Naples, 150-175.

Tafel, Gottlieb Lukas Friedrich / Thomas, Georg Martin (1855), Der Doge Andreas Dandolo und die von demselben angelegten Urkundensammlungen zur Staats- und Handelsgeschichte Venedigs mit den Original-Registern des Liber albus, des Liber blancus und der Libri Pactorum aus dem Wiener Archiv, Munich. 
Tomasi, Michele (2008), “Prima, dopo, attorno alla Cappella: il Culto di Sant'Isidoro a Venezia”, in: La Cappella di Sant'Isidoro (Quaderni della Procuratoria. Arte, Storia, Restauri della Basilica di San Marco a Venezia), 15-23.

Tomasin, Lorenzo (2001), Il Volgare e La Legge. Storia Linguistica del Diritto Veneziano: Secoli XIIIXVIII, Padua.

Tomasin, Lorenzo (2016), “Urban Multilingualism. The Languages of Non-Venetians in Venice during the Middle Ages", in: Maria Selig and Susanne Ehrich (eds.), Mittelalterliche Stadtsprachen, Regensburg, 63-75.

Valerio, Agostino (1787), Dell'utilità che si può Ritrarre dalle Cose Operate dai Veneziani Libri 14, del Cardinale Agostino Valerio [...] Tradotti dal Latino e Illustrati da Monsignor Niccolò Antonio Giustiniani, Padua.

Venezia e La Peste, 1348-1797 (1980²), Venice.

\section{Photo Credits}

Fig. 1: Public Domain. Source: Wikimedia Commons. Original Source: Encyclopedia Britannica, $11^{\text {th }}$ Edition (1911), 393.

Fig. 2-5: Archivio Fotografico della Procuratoria di San Marco.

Fig. 6: Author. Courtesy of Archivio Fotografico della Procuratoria di San Marco.

Fig. 7: Archivio Fotografico della Procuratoria di San Marco.

Fig. 8: Mario Carrieri. 
